\title{
Pelatihan desain media interaktif pada pembelajaran daring bagi dosen pendidikan biologi
}

\author{
Taufik Samsuri' ${ }^{1}$, Agus Muliadi*2, Muhali ${ }^{3}$, Muhammad Asy'ari ${ }^{4}$, \\ Saiful Prayogi ${ }^{5}$, Hunaepi ${ }^{6}$ \\ 2*agusmuliadi@ikipmataram.ac.id \\ 1,2,6Pendidikan Biologi, Universitas Pendidikan Mandalika \\ ${ }^{3}$ Pendidikan Kimia, Universitas Pendidikan Mandalika \\ ${ }^{4}$ Pendidikan Olahraga, Universitas Pendidikan Mandalika \\ ${ }^{5}$ Pendidikan Fisika, Universitas Pendidikan Mandalika
}

Received: 11 November 2020 Accepted: 27 Desember 2020 Online Published: 31 Desember 2020 DOI: 10.29408/ab.v1i2.2745 URL: http://dx.doi.org/10.29408/ab.v1i2.2745

\begin{abstract}
Abstrak: Pembelajaran daring merupakan perturan yang dikeluarkan oleh Kementrian Pendidikan dan Kebudayaan sebagai langkah strategis dalam upaya pencegahan penyebaran virus Covid-19. Efektivitas pembelajaran daring dipengaruhi oleh kualitas media pembelajaran yang digunakan oleh dosen. Oleh sebab itu, diperlukan adanya pelatihan untuk menguatkan keterampilan dosen dalam menyusun media interaktif yang efektif dalam pembelajaran daring. Tujuan kegiatan ini adalah untuk meningkatkan pengetahuan dan keterampilan Dosen Pendidikan Biologi tentang desain media interaktif pada pembelajaran daring. Peserta kegiatan ini adalah Dosen Pendidikan Biologi FSTT Universitas Pendidikan Mandalika sebanyak 27 orang. Kegiatan pelatihan dibagi menjadi tiga tahap diantaranya: (1) Persiapan, (2) Pelaksanaan, (3) Refleksi/Evaluasi. Kegiatan pelatihan diselenggarakan secara online/webinar pada hari Sabtu/25 Juli 2020 pukul 07.00-12.00 Wita dengan susuan acara yaitu pembukaan, sambutan Ketua Program Studi Pendidikan Biologi, penyampaian materi pelatihan, diskusi, penyampaian kesan dan pesan. Kegiatan pelatihan terlaksana dengan baik walaupun ada beberapa kekurangan. Hal ini didukung dengan kesan-pesan peserta di akhir kegaitan yaitu (1) $100 \%$ peserta pelatihan memberikan respon positif seperti merasa senang, semangat, antusias, dan terbantu atas diadakannya kegiatan pelatihan ini; (2) $75 \%$ peserta memberikan saran agar kegaitan pelatihan sejenis dapat dilakukan secara berkala pada awal persiapan tiap semester. Pada akhirnya peserta memiliki pengetahuan dan keterampilan dalam mendesain media interaktif pada pembelajaran daring.
\end{abstract}

Kata kunci: Desain Media Interaktif; Pembelajaran Daring

Abstract: Online learning is a national policy as a strategic step to prevent the spread of the Covid-19 virus. The quality of the learning media used by lecturers is to influence the effectiveness of online learning. Therefore, training is needed to strengthen lecturers' skills in developing interactive media effective in online learning. This community service aims to improve the biology education lecturers' knowledge and skills regarding interactive media design in online learning. Participants of this activity were 27 Lecturers of Biology Education at FSTT Mandalika University of Education. The training activity is carried out in three stages, namely (1) Preparation, (2) Implementation, (3) Reflection / Evaluation. Training activities are held online / webinar on Saturday / 25 July 2020 at 07.00-12.00 WITA with a series of events, namely opening, remarks from the Head of the Biology Education Study Program, delivery of training materials, discussions, conveying impressions and messages. The training activities were carried out well, even though there were some shortcomings. This is supported by the participants' messages at the end of the activity, namely (1) 100\% of the training participants gave positive responses such as feeling happy, enthusiastic, enthusiastic, and helped by the holding of this training activity; (2) $75 \%$ of participants gave suggestions so that similar training activities could be carried out periodically at the beginning of preparation for each semester. In the end, the participants have the knowledge and skills in designing interactive media in online learning.

Keyword: Interactive Media Design; Online Learning 


\section{PENDAHULUAN}

Masyarakat dunia saat ini sedang dihadapkan dengan pandemi corona virus disease 2019 (Covid-19). Sejak diumumkannya status pandemi COVID-19 di seluruh dunia oleh WHO pada bulan Maret 2020, telah menyebabkan dampak buruk di berbagai sektor (Cao et al., 2020; Nicola et al., 2020; Richards et al., 2020; Muthiadian, dkk. 2020). Indonesia sendiri telah merambah ke dunia pendidikan seperti Perguruan Tinggi. Pemerintah pusat hingga daerah membuat kebijakan untuk melawan wabah Covid-19 yaitu dengan mengeluarkan larangan berkerumun, pembatasan sosial (social distancing) dan menjaga jarak fisik (physical distancing), memakai masker dan selalu cuci tangan (Gultom \& Sitanggang, 2020; Sadikin \& Hamidah, 2020). Pemerintah pusat hingga daerah memberikan kebijakan untuk meliburkan pembelajaran secara langsung di seluruh lembaga pendidikan termasuk Perguruan Tinggi. Hal ini sesuai dengan Surat Edaran Menteri Pendidikan dan Kebudayaan Nomor 3 Tahun 2020. Kebijakan ini mengharuskan perguruan tinggi untuk menyelenggarakan pembelajaran secara online (daring) (Firman \& Rahayu, 2020). Terasne, dkk. (2020) Kebijakan ini dilakukan guna memutus rantai persebaran COVID-19. Dan hal ini tidak hanya terjadi di Indonesia namun di seluruh dunia (Agustin, 2020). Menindaklanjuti edaran kemendikbud tersebut, semua perguruan tinggi merespon, termasuk Universitas Pendidikan Mandalika dengan meniadakan perkuliahan konvesional dan menggantinya dengan pembelajaran daring. Oleh sebab itu, peroses pembelajaran pada Program Studi Pendidikan Biologi Fakultas Sains, Teknik, dan Terapan (FSTT) Universitas Pendidikan Mandalika dilaksanakan dari rumah dengan memanfaatkan teknologi internet secara synchronous atau asynchronous.

Perkembangan teknologi informasi komunikasi di Era Revolusi Industri 4.0 yang pesat memudahkan dalam keberlangsungan perkuliahan daring. Media sosial dapat dijadikan media pembelajaran daring karena dapat digunakan berkomunikasi antar muka, berpartisipasi, dan berbagi. Pemberlakuan pembelajaran daring dengan mengubah pembelajaran konvensional menjadi online secara tidak langsung menguji keprofesionalitasan dosen dalam mengajar. Dosen diharuskan untuk dapat berinovasi dalam menyampaikan materi perkuliahan melalui berbagai aplikasi dan media yang interaktif (Pangondian, Santosa, \& Nugroho, 2019). Pembelajaran daring mempunyai teknis yang berbeda dari model pembelajaran sistem tatap muka. Pembelajaran full online memudahkan pelaksanaannya karena dapat diakses dari mana saja dengan mengandalkan jaringan internet. Tidak hanya itu, perkuliahan daring juga memudahkan dosen dan mahasiswa dalam menentukan aplikasi pembelajaran yang tersedia, model komunikasi, dan media pembelajaran yang efektif. Oleh sebab itu, pembelajaran daring diharapkan dapat terwujud dalam bentuk interaksi secara timbal balik yang dinamis antara mahasiswa dengan dosen, baik itu interaksi dua arah atau semi dua arah (Maulah, Nurul, \& Ummah, 2020).

Pelaksanaan pembelajaran daring pada Program Studi Pendidikan Biologi FSTT Universitas Pendidikan Mandalika mengalami beberapa kendala umum yaitu minimnya jaringan internet, ketersediaan perangkat pembelajaran (salah satunya laptop), suasana rumah dan lingkungan sekitar yang tidak mendukung juga turut menentukan efektifitas pembelajaran daring. Efektivitas pembelajaran daring juga dipengaruhi oleh kualitas media pembelajaran interaktif yang digunakan oleh dosen. Hal ini mengakibatkan adanya kesulitan yang dialami mahasiswa dalam memahami materi perkuliahan. Oleh sebab itu, diperlukan adanya pelatihan 
untuk menguatkan keterampilan dosen dalam menyusun media interaktif yang efektif dalam pembelajaran daring.

\section{METODE PELAKSANAAN}

Kegiatan pengabdian ini dilakukan dengan menggunakan metode partisipatif, yaitu pendekatan yang berorientasi kepada upaya peningkatan peran serta dosen dalam berbagai proses dan pelaksanaan. Peserta dalam kegiatan ini adalah Dosen Pendidikan Biologi sebanyak 27 orang. Adapun tahapan pelaksanaan kegiatan ini adalah sebagai berikut:

1. Peserta Kegiatan

Peserta kegiatan pengabdian ini adalah Dosen Pendidikan Biologi, Fakultas Sains, Teknik, dan Terapan (FSTT) Universitas Pendidikan Mandalika.

2. Tahap Persiapan

Pada tahap ini dilakukan koordinasi dengan Ketua Program Studi dan mendiskusikan tentang waktu pelaksanaan, susunan acara, waktu pelaksanaan, operator, moderator, serta teknis lainnya agar sesuai dengan protokol kesehatan dan physical distancing. Kegiatan akan dilakukan dalam bentuk pelatihan online.

3. Tahap Pelaksanaan

Kegiatan pelatihan dilaksanakan dengan tujuan untuk meningkatkan pengetahuan dosen dalam mendesain media interaktif pada pembelajaran daring. Kegiatan pelatihan dilakukan secara online (webinar) pada hari Sabtu/25 Juli 2020, pukul 07.00-12.00 Wita. Aplikasi yang digunakan adalah zoom meeting.

4. Tahap Refleksi (Evaluasi)

Pada tahap ini dilakukan refleksi melalui evaluasi di akhir kegiatan dengan meminta tanggapan atau respon peserta terhadap kegiatan pelatihan yang diselenggarakan. Pendapat disampaikan secara terbuka setelah melalui kolom komentar pada aplikasi zoom meeting.

\section{HASIL DAN PEMBAHASAN}

Kegiatan pelatihan tentang desain media interaktif pada pembelajaran daring dilaksanakan pada hari Sabtu/25 Juli 2020. Tujuan kegiatan ini adalah untuk meningkatkan pengetahuan dosen Pendidikan Biologi tentang desain media interaktif pada pembelajaran daring pada masa pandemi covid-19 saat ini. Susunan acara pelatihan dilakukan dalam tiga tahap yaitu (1) Pembukaan, (2) Sambutan ketua Program Studi Pendidikan Biologi, (3) Penyampaian materi pelatihan, (3) diskusi, (4) refleksi (evaluasi). Adapaun rincian kegiatan tersebut yaitu:

1. Pembukaan, dipandu oleh pembawa acara yaitu ibu Any Fatmawati, M.Pd salah satu dosen Pendidikan Biologi. Kegiatan dimulai dengan membuka acara pembukaan yaitu dengan mengucapkan Basmallah.

2. Sambutan Ketua Program Studi disampaikan oleh ibu Dr. Ika Nurani Dewi, M.Pd. Pada sambutannya diawalaing dengan apresiasi atas kegiatan pelatihan yang dilaksanakan oleh tim pengabdian, selanjutnya dipaparkan dengan visi-misi dan rencana strategis Program Studi terkait dengan kegiatan pengembangan kualitas pembelajaran melalui inovasi media pembelajaran berbasis teknologi informasi.

3. Penyampaikan materi pelatihan dilakukan oleh ketua pelaksana Bapak Taufik Samsuri dan dibantu oleh anggota tim. Pada kesempatan ini disampaikan materi tentang media 
interaktif yang menarik pada pembelajaran daring, desain media interaktif, dan teori-teori yang mendukung. Kemudian, dilakukan tutorial tahapan pembuatan media interaktif seperti power point yang menarik dan integratif dengan animasi dan video. Peserta pelatihan diberikan tugas untuk membuat media interaktif dilakukan secara mandiri dan akan didampingi secara online setelah kegiatan pelatihan online.

4. Diskusi dilakukan setelah narasumber menyampaikan materi dan tutorial tentang desain media interaktif. Sesi diskusikan dilakukan dalam dua termin dengan 4 orang penanya. Pada tahap ini diketahui bahwa peserta umumnya bertanya tentang cara mendesain media power point yang menarik dengan mengintegrasikan animasi dan video.

5. Pada tahap akhir kegiatan pelatihan online dilakukan refleksi dengan meminta kesan dan pesan peserta terhadap kegiatan pelatihan online. Respon peserta dituliskan pada kolom komentar aplikasi zoom meeting dengan waktu 5 menit. Hal ini diperlukan untuk evaluasi kegiatan pelatihan demi perbaikan ke depannya.

6. Penutup sebagai akhir dari kegiatan pelatihan yaitu dipandu oleh pembawa acara dengan susunan acara ucapan terima kasih kepada mitra oleh ketua pelaksana.

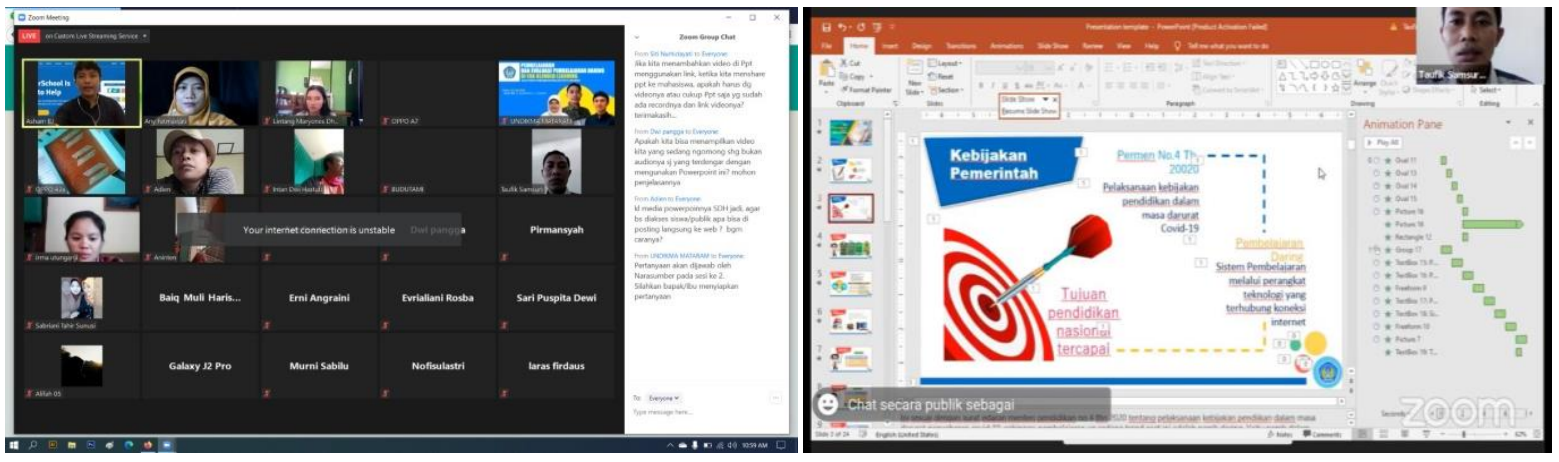

Gambar 1. Kegiatan pelatihan media interaktif secara online

Kegiatan pelatihan diikuti dengan antusias oleh 27 orang Dosen Pendidikan Biologi FSTT Universitas Pendidikan Mandalika. Hal ini menunjukkan bahwa peserta menyadari akan pentingnya kegiatan pelatihan untuk meningkatkan pengetahuan dan keterampilan dalam membuat media interaktif pada pembelajaran daring selama covid-19 saat ini. Berdasarkan dari refleksi pada akhir sesi kegiatan pelatihan, diperoleh informasi bahwa peserta mengapresiasi dan mendukung pelaksanaan pelatihan media seperti ini untuk rutin dilaksanakan pada persiapan sebelum perkuliahan dimulai setiap semesternya. Hal ini dirasa penting agar dosen dapat terus memperbaharui media yang digunakan dalam perkuliahan.

Peserta sebelum diberikan pelatihan sudah sering menggunakan media pembelajaran sesuai dengan kemampuan masing-masing. Seluruh peserta menyatakan memiliki pengetahuan awal dalam membuat media pembelajaran, namun belum mampu mendesain secara menarik dengan mengintegrasikan animasi dan video. Oleh sebab itu, kegiatan pelatihan ini sangat penting untuk meningkatkan pengetahuan dan keterampilan dosen pendidikan biologi. Peserta berharap setiap materi perkuliahan dapat disajikan ke dalam media pembelajaran yang berbasis interaktif, sehingga mahasiswa termotivasi dan mudah mengerti materi perkuliahan. Hal ini sesuai dengan pendapat Hartono, et al (2018) bahwa media salah satu penunjang dalam proses pembelajaran. Berhasil dan tidaknya proses pembelajaran sangat ditentukan oleh media yang digunakan. 


\section{SIMPULAN}

Berdasarkan hasil observasi dan refleksi/evaluasi dari pelaksanaan kegiatan pelatihan online dapat disimpulkan bahwa kegiatan pelatihan terlaksana dengan baik walaupun ada beberapa kekurangan. Hal ini didukung dengan kesan-pesan peserta di akhir kegaitan yaitu (1) $100 \%$ peserta pelatihan memberikan respon positif seperti merasa senang, semangat, antusias, dan terbantu atas diadakannya kegiatan pelatihan ini; (2) 75\% peserta memberikan saran agar kegaitan pelatihan sejenis dapat dilakukan secara berkala pada awal persiapan tiap semester. Pada akhirnya peserta memiliki pengetahuan dan keterampilan dalam mendesain media interaktif pada pembelajaran daring.

\section{UCAPAN TERIMA KASIH}

Kegiatan pengabdian dengan judul "Pelatihan Desain Media Interaktif Pada Pembelajaran Daring Bagi Dosen Pendidikan Biologi” dapat terlaksana dengan baik atas bantuan banyak pihak. Khususnya kami sampaikan terima kasih kepada (1) Ibu Ketua Program Studi Pendidikan Biologi, (2) Dosen Pendidikan Biologi, (3) Fakultas Sains, Teknik, dan Terapan (FSTT) Universitas Pendidikan Mandalika.

\section{PERNYATAAN PENULIS}

Artikel ini merupakan hasil karya sendiri yang belum pernah dipublikasikan baik secara keseluruhan maupun sebahagian, dalam bentuk jurnal, working paper atau bentuk lain yang dipublikasikan secara umum. Karya ilmiah ini sepenuhnya merupakan karya intelektual dan seluruh sumber yang menjadi rujukan dalam karya ilmiah ini telah sebutkan sesuai kaidah akademik yang berlaku umum, termasuk para pihak yang telah memberikan kontribusi pemikiran pada isi, kecuali yang menyangkut ekspresi kalimat dan disain penulisan.

\section{DAFTAR PUSTAKA}

Agustin L.L.T., (2020) Dampak Pembelajaran Daring Dengan Whatssapp Group Pada Prilaku Kreatif Siswa (Studi Kasus Pembelajaran Di Kelas IV SD Terangmas Undaan Kudus). https://www.researchgate.net/publication/342762494

Cao, W., Fang, Z., Hou, G., Han, M., Xu, X., Dong, J., \& Zheng, J. (2020). The psychological impact of the COVID-19 epidemic on college students in China. Psychiatry research, 287, 1-5. https://doi.org/10.1016/j.psychres.2020.112934.

Firman, F., \& Rahayu, S. 2020. Pembelajaran Online di Tengah Pandemi Covid-19. Indonesian Journal of Educational Science (IJES), $2 \quad$ (2), 81-89. https://doi.org/10.31605/ijes.v2i2.659

Gultom, C.R. \& Sitanggang, S.G.M. 2020. Persepsi Mahasiswa Unika terhadap Kuliah Online di Masa Pandemi Covid 19. Jurnal Pendidikan Bahasa Indonesia dan Sastra (PEDISTRA), 3 (1), 6-15. http://dx.doi.org/10.1234/pbis.v3i1.771

Hartono, Lesmana, C., Permana, R. \& Matsun. 2018. Pelatihan dan Pendampingan Pembuatan Media Pembelajaran Berbasis Multimedia Interaktif. Jurnal Transformasi, 14 (2), 139147. http://dx.doi.org/10.29406/al-khidmah.v1i2.1216

Nicola, M., Alsafi, Z., Sohrabi, C., Kerwan, A., Al-Jabir, A., Iosifidis, C., Agha, M., Agha, R. (2020). The socio-economic implications of the coronavirus pandemic (COVID-19): A 
Samsuri, T., Muliadi, A., Muhali, M., \& Asy'ari, M. (2020). Pelatihan desain media interaktif pada pembelajaran daring bagi dosen pendidikan biologi. ABSYARA: Jurnal Pengabdian Pada Masyarakat, 1(2), 30-35. doi:10.29408/ab.v1i2.2745

$\begin{array}{lllll}\text { review. International journal of surgery, } & 78, & 185-193 .\end{array}$ https://dx.doi.org/10.1016\%2Fj.ijsu.2020.04.018.

Maulah, S., Nurul, F. \& Ummah, N.R. 2020. Persepsi Mahasiswa Biologi terhadap Perkuliahan Daring sebagai Sarana Pembelajaran Selama Pandemi Covid-19. ALVEOLI: Jurnal Pendidikan Biologi, $1 \quad$ (2), 49-61. $\quad$ https://alveoli.iainjember.ac.id/index.php/alv/article/view/6

Muthiadin, C., Aziz, I. R., Hajrah. H., Alir, R. F. (2020). Edukasi dan Pelatihan Desain Infografis COVID-19 bagi Siswa dan Guru SMAN 10 Makassar. Sasambo: Jurnal Abdimas (Journal of Community Service). 2(3), 153-162 DOI : 10.36312/sasambo.v2i3.313

Terasne., Permana., D. Salim.., A. Utama., P.I., Hanan., A.(2020) Pelatihan Pemanfaatan Google Classroom Sebagai Media Pembelajaran Altenatif Pada Masa Covid 19 Bagi Guru SMPN 1 Praya Barat. Sasambo: Jurnal Abdimas (Journal of Community Service). 2(3), 95-100. DOI : 10.36312/sasambo.v2i3.232

Pangondian, R. A., Santosa, P. I., \& Nugroho, E. 2019. Faktor-Faktor Yang Mempengaruhi Kesuksesan Pembelajaran Daring Dalam Revolusi Industri 4.0. Seminar Nasional Teknologi Komputer \& Sains (SAINTEKS), 1 (1), 56-60. https://www.prosiding.seminarid.com/index.php/sainteks/article/view/122

Richards, T. J., Rickard, B. (2020). COVID-19 impact on fruit and vegetable markets. Canadian Journal of Agricultural Economics, 68(2), 189-194. https://doi.org/10.1111/cjag.12231.

Sadikin, A. \& Hamidah, A. 2020. Pembelajaran Daring di Tengah Wabah Covid-19. BIODIK: Jurnal Ilmiah Pendidikan Biologi, 6 (2), 214-224. https://doi.org/10.22437/bio.v6i2.9759 